\title{
Rural Modernity: An oxymoron or a new vision?: Interview with Andrea Ferrante
}

ANGELA ZARRO

\begin{abstract}
In this interview, Andrea Ferrante explains what a sustainable agricultural transformation shall mean and imply from the point of view of small farmers, local producers, rural communities and indigenous people, as presented also in the Declaration of Nyéléni 2015. Ferrante argues that such transformation is already happening through people's experience and practices at local level worldwide.
\end{abstract}

KEYWORDS agroecology; smallholders farmers; grassroots; human rights; food sovereignty; food and agricultural policy; sustainable transformation; innovation

\section{Introduction}

'Transformation' is undoubtedly one of the keywords of the sustainable development goals' era. Indeed, 'transformation' is envisaged to take place across sectors and countries, in other words universally. The need for a real transformation is being called for by different constituencies worldwide (policymaking, research, civil society, private sector) as necessary to achieve the new development goals. However, unless this transformation involves profound changes in the current economic, political and social structures, it will remain an empty concept and nothing more than a new development buzzword. Is it going to address the current model of economic globalization, which is contributing to a process of homogenization, marginalization of diversity and perpetration of inequalities and insecurities within people, countries and societies? Can a different system - respectful of people's knowledge and environment - be possible, building on progress, technology and innovation, strengthening rather than damaging local rural economies and societies?

In this interview, Ferrante explains what a sustainable agricultural transformation shall mean and imply from the point of view of small farmers, local producers, rural communities and indigenous people, as also presented in the Declaration of Nyéléni 2015 (published in this journal issue, page). Ferrante argues that such transformation is already happening worldwide through people's experience and practices at local level. It embodies the new vision of agroecology, where tradition and innovation come together strengthening the economic viability of rural areas, generating new knowledge, building on ecological principles of production, nurturing identity and culture, prioritiz-

ing rights over profits. From this point of view, the real innovation is coming from the 
rural endeavors and therefore it is of paramount importance that smallholder farmers and local food producers - who represent the 90 percent of the overall world food production - are part of the broader development discourse at global level. Rural modernity - through a process of sustainable transformation - is possible as long as people's human rights and food sovereignty are respected.

AZ: The agenda 2030 is built on a transformative approach that is sustainable and participative. What shall this transformation mean and imply from the point of view of local rural communities and grassroots?

AF: The reality around us goes through continuous transformation and human beings are always responding to the change, trying to adapt themselves and find answers to the new emerging challenges. With this premise, it must be clear that a sustainable transformation can only be framed within the human rights-based approach and the concept of food sovereignty.

Such transformation is actually already taking place, practiced by people and local communities all over the world. This is what we call agroecology. There is no need for a new concept or a new paradigm. Agroecology is the translation of something already existing in the territories, based on people's knowledge and experience. It builds on the idea of an alternative society whose principles are based on ecological practices, but at the same time are framed within a very clear social context.

The answer to people's basic needs must be found in the respect and recognition of their rights. This is what the human rights approach and the concept of food sovereignty shall mean and imply. That is the only way forward for us.

By practicing agroecology within their territories, people and local communities worldwide have anticipated such transformation. They did not wait! While policymakers are still trying to find solutions (think for instance at a key issue such as climate change), local communities and grassroots movements are actually leading the way to find solutions. They are building the solution, as they are within the solution! There is giant capacity and knowledge already on these territories. This is why the 2015 Nyélény Forum ${ }^{1}$
AZ: As you are mentioning the Nyéléni Forum, it would be interesting to add a few words about its purpose and political relevance.

AF: The Nyélény Forum was conceived as a moment for all - food producers, peasants, fisherfolk, pastoralists, Indigenous Peoples - to gather together and agree a set of common principles. Despite the discussion was mainly focused on agricultural issues, fisherfolk and other food producers coming from different sectors, found a commonality of values and principles in the way they produce food. They are all respecting and sharing the same principles of agroecology. Names and definitions of agroecology can be different depending on regions and territories, but the approach and the values are the same. Agroecology clearly shows how people are putting the agenda on food sovereignty in practice. This is precisely what agroecology is about, today.

AZ: In terms of policy impact, what are the main challenges? How can agroecology principles be 'mainstreamed' into public policies, markets and societies? Is there a gap and where?

AF: The gap is huge, because today food policies are not based on the right to adequate food and on the human rights approach. Most of the food and agricultural policies are based on agreements on agriculture established within the framework of the World Trade Organization. The distance between the policy context and reality could not be greater. We are talking about food and agricultural policies complying with trade agreements relating to international food and agricultural commodities that represent only the 10 percent of the overall agricultural production. As the other 90 percent is produced and consumed locally, there is no reason why food and agricultural policies should comply with international trade policies! A total shift is required! In this case, yes, we need a policy paradigm shift. Food and agricultural policies cannot be rooted on trade agreements. They must be rooted on rights! Then agroecology will be mainstreamed and make a big difference.

AZ: Can you provide an example?

AF: The breeding techniques of transnational corporations, for instance, are not the answer: they are very specific, subject to patents and are 


\section{Zarro: Rural Modernity?}

producing seeds that are useless for us. That is clear and evident. On the other hand, in order to have farmers' seeds, it is necessary to recognize the right to the farmers to have and use their own seeds. It means recognizing people's rights and changing the cultural framework. That is why it is important to shift toward food and agricultural policies based on the human rights approach and food sovereignty. Otherwise, it is impossible for these policies to challenge hunger, rural poverty and malnutrition.

AZ: Regarding the issue of international vs local trade, how would you respond to those cautioning about market protectionism?

AF: The impact of local trade is almost insignificant on international trade. Actually, it is the other way around. It is international trade to have a possible huge impact on local trade and economies. Trade rules on sanitary and phytosanitary measures, for instance, may have dramatic consequences on local markets and productions. On the contrary, an increasing number of studies are providing evidence that public procurements giving priority to smallholders and being a great potential for them - have no effect on international trade.

Furthermore, let us be clear about one point: it is not the international trade production, but rather the smallholder farming - representing the vast majority of food producers in the world - that is feeding the world population today! International trade is in the hands of few corporations doing big business and making money out of that, but it is not feeding the world! As a consequence, it is not acceptable to have food and agricultural policies benefiting these few corporations at the disadvantage of those feeding the world. A dramatic change of public policies is indeed required, today, because public policies are not really addressing the needs and demands of the majority.

AZ: With regard to the concept of rural modernity - which gives the title to the interview - can tradition and innovation be reconciled? At what price? Which are the demands, needs, feelings of rural communities, Indigenous Peoples, small farmers and food producers, with regards to progress and technology vis-à-vis their traditional knowledge and cultural heritage?
AZ: If a sustainable and oil free society is our future - as also envisaged by the mainstream development thinking - the rural society stands as the most innovative one. Peasants and rural people are already putting this in practice. They are already part of the innovation process of society. Peasants are the heart and the engine of food production and - why not - of energy production as well. In that sense, the rural society can be one of the most innovative form of society.

Rural society is often thought as something backward. Today, as we are reaching the limits of an unsustainable model, there is a growing tendency to go back to the rural dimension, working and building on traditional knowledge. This does not mean remaining stuck to a knowledge base that is hundred years old. It is a cultural issue. Knowledge is always changing. The key issue is related to which is actually controlling such knowledge! Innovation, technology, knowledge: once again, it is a question of rights. Rural people account for one and a half billion farmers and food producers worldwide and they must be allowed to exercise the right to use their own knowledge and to access open source technology (rather than being obliged to use foreign technology by trade rules).

AZ: Which are the strengths and weaknesses for local rural communities to succeed against the process of homogenization and increasing inequalities perpetrated by the current form of globalization? How can local economies become viable despite the increasingly open competition of large companies and influence of market forces?

AF: There is no single answer to that. Of course, public policies play a fundamental role. However, a very important principle of agroecology is related to the territory, the community and the capacity of people to organize themselves and mobilize. Without building strong organizations, strong communities, strong territories, it is impossible to fight those kind of powers. That is clear and evident. The territories - where different societies and different sectors link up together and create alliances - are the answers. Local systems are much more resilient, and people, if organized within their communities, can have the strength to mobilize and resist to attacks. For instance, in the case of land 


\section{Development 58(2-3): Upfront}

grabbing, if it is only the single farmer to react, the protective response may fail; but if it is the entire community to mobilize, the land grabber will not succeed.

AZ: Where are we in this process?

AF: Lots of work remains to be done because public policies and mainstream markets are destroying our territory, our social links and our capacity to work together. The increasing individualism is a key problem. The continuous attempt to provide individualistic answers to collective problems is weakening society and the capacity of communities to find collective answers. Against this, there is an urgent need to reinforce the community (of course, this is no easy task because most dynamics at play are pushing in the opposite direction). This is the strength of agroecology: the vision of a society working together to give collective responses. This is what we need to do more and more.

\section{Note}

1 The International Forum on Agroecology was organized at the Nyéléni Center in Mali, from 24 to 27 February 2015 by the following organisations: Coordination Nationale des Organisations Paysannes du Mali as chair; La Via Campesina, Movimiento Agroecológico de América Latina y el Caribe, Réseau des organisations paysannes et de producteurs de l'Afrique de l'Ouest, World Forum of Fish Harvesters and Fishworkers, World Forum of Fisher Peoples, World Alliance of Mobile Indigenous Peoples, More and Better. More information can be found at the following address: www.foodsovereignty.org/forum-agroecology-nyeleni-2015/ 